\title{
The Management of Performance Anxiety with Beta-Adrenergic Blocking Agents
}

James A. Bourgeois, M.D.

Wright State University School of Medicine, Dayton, Ohio

Follow this and additional works at: https://jdc.jefferson.edu/jeffjpsychiatry

Part of the Psychiatry Commons

Let us know how access to this document benefits you

\section{Recommended Citation}

Bourgeois, M.D., James A. (1991) "The Management of Performance Anxiety with Beta-Adrenergic Blocking Agents," Jefferson Journal of Psychiatry. Vol. 9 : Iss. 2 , Article 5.

DOI: https://doi.org/10.29046/JJP.009.2.002

Available at: https://jdc.jefferson.edu/jeffjpsychiatry/vol9/iss2/5

This Article is brought to you for free and open access by the Jefferson Digital Commons. The Jefferson Digital Commons is a service of Thomas Jefferson University's Center for Teaching and Learning (CTL). The Commons is a showcase for Jefferson books and journals, peer-reviewed scholarly publications, unique historical collections from the University archives, and teaching tools. The Jefferson Digital Commons allows researchers and interested readers anywhere in the world to learn about and keep up to date with Jefferson scholarship. This article has been accepted for inclusion in Jefferson Journal of Psychiatry by an authorized administrator of the Jefferson Digital Commons. For more information, please contact: JeffersonDigitalCommons@jefferson.edu. 


\title{
The Management of Performance Anxiety with Beta-Adrenergic Blocking Agents
}

\author{
James A. Bourgeois, M.D.
}

\begin{abstract}
Performance anxiety consists of several symptoms experienced in the context of public performance and is classified in DSM-III-R under social phobia. Performance anxiety must be distinguished from panic disorder, generalized social phobia, and generalized anxiety disorder. Performance anxiety symptoms can be detrimental to both performer and performance. These symptoms can be controlled by the judicious use of beta-adrenergic blocking agents. The use of beta-adrenergic blocking agents should be considered as part of a psychiatric stress-management program for these patients.
\end{abstract}

The phenomenon of performance anxiety (or "stage fright") has been appreciated for many years. The symptoms are noted immediately prior to and during various performance tasks, e.g., music, public speaking, athletics, and test taking, and are referable to the sympathetic nervous system. Although no standard series of symptoms specific to this condition has been developed, tachycardia/palpitations, tremor, and sweating are cited most commonly, with various other symptoms listed less consistently (1-16, Table 1).

A small, manageable amount of autonomic arousal may well be adaptive by serving to increase the performer's energy. For many other performers, however, these symptoms are excessive and counterproductive. Witness the violinist or archer with excessive tremor, the trumpeter with dry mouth and shortness of breath, or the actor with excessive sweating. This paper will examine the evaluation and management of performance anxiety symptoms.

\section{DESCRIPTION AND DIFFERENTIAL DIAGNOSIS}

Performance anxiety is classified in DSM-III-R as social phobia (300.23) (17). These criteria include: a persistent fear of situations in which the person is exposed to scrutiny by others, and fears that he/she may act in a humiliating or embarrassing manner; exposure to the stimulus provokes an anxiety response; the phobic situation is avoided or endured with great anxiety; and the avoidant behavior interferes with occupational functioning. DSM-III-R distinguishes between those persons with "generalized" social phobia from those with "discrete" social phobia which is limited to performance situations by the caveat that the generalized type describes those persons for whom the phobia situation includes most social situations. A study by 
Heimberg, Hope, Dodge, and Becker (18) compared a group of generalized social phobics to a group who were phobic for public speaking only. They found the generalized social phobics to be lower-functioning, and to have more severe phobic symptoms than the public speaking phobics. The public speaking phobics were found to have a noticeably greater increase in heart rate in response to a performance challenge, as well as overestimating the visibility of their anxiety symptoms and underestimating the quality of their performance while being observed.

Turner and Beidel (19) studied a population of socially anxious persons who were asked to give a speech. They found a significant increase in blood pressure during the performance task for a subgroup described with "high physiological reactivity." Their study did not use DSM-III criteria for social phobia, and the specific symptoms of performance anxiety vs. generalized social phobia were not addressed.

An important distinction must be made between social phobia and panic disorder. Although the physical and cognitive symptoms of the two conditions show considerable overlap, the panic disorder patient experiences symptom attacks as unexpected and not triggered by situations in which the person is the focus of attention by others (17). When the panic disorder patient develops phobic avoidance of social situations, it is after the onset of panic disorder and due to fear of having a panic attack (often in a nonsocial situation), while the social phobic is afraid of acting in an embarrassing or humiliating way (20). The distinction between social phobia and panic disorder has both diagnostic and therapeutic importance, as treatment with tricyclic antidepressants is recommended for panic disorder, but is generally ineffective for social phobia (21). To illustrate this point, Pohl, Balon and Yeragani (22) reported a case of a musician who first developed panic attacks in a variety of situations. Eventually, the symptoms of palpitations, sweating, chest tightness, trembling, feelings of panic and fears of "going crazy" occurred only with musical performance. He responded briefly to propranolol, but eventually was successfully treated with imprimine. Because his initial symptoms were spontaneous, this patient is more accurately described as having panic disorder rather than social phobia.

It is postulated that patients with social phobia limited to performance situations are unusually responsive to the peripheral somatic cues that result from adrenergic activation (21). There is some evidence that such patients show a more dramatic cardiovascular response to stressful performance stimuli (18). The patient notices the somatic symptoms (which nearly uniformly include tachycardia, sweating, and tremor) and then develops a cognitive percept that others will be particularly perceptive of these somatic symptoms $(18,21)$. This results in a vicious cycle wherein the somatic symptoms lead to the hypersensitive cognitions, leading to greater peripheral symptoms in a positive feedback loop. This proposed mechanism is in contrast to the centrally driven mechanism felt to be responsible for panic disorder. Leibowitz, Gorman, Fyer and Klein noted that DSM-III social phobia patients had a substantially lower incidence of lactate-induced panic symptoms than did patients suffering from panic disorder with agoraphobia, further supporting a neurochemical difference between these two conditions (21).

Social phobia must also be distinguished from avoidant personality disorder, 
which represents a more long-standing pattern of social avoidance with less likelihood of discrete episodes of physical symptoms. Patients with social phobia are also prone to affective illness and substance abuse, which may be attempts to manage anxiety symptoms (17). Agras (15) noted a significant incidence of complete avoidance of the phobic situation, occupational change, and anticipatory use of alcohol in patients with public speaking or musical performance forms of social phobia.

\section{PERFORMANCE ANXIETY IN PERFORMER GROUPS}

The frequency of intrusive performance anxiety even among seasoned performers is surprisingly high. Performance anxiety does not necessarily decrease with either increasing musical proficiency or performance experience. Among well-known performers, Arthur Rubenstein, Pablo Casals, and Carly Simon are said to have suffered from significant performance anxiety (23). Wesner, Noyes, and Davis (10), in a survey of university music students and faculty, found that $16 \%$ of the respondents felt that their performance was markedly impaired by their anxiety symptoms, with poor concentration, rapid heartbeat, tremor, sweating and dry mouth the most commonly reported performance anxiety symptoms. Auditions and solo performances (wherein the player is the most exposed to the listener's scrutiny) were cited as being "quite a bit" or "extremely" anxiety provoking by a majority of the respondents. The authors also asked about other anxiety symptoms including panic attacks and reported that $27 \%$ and $34 \%$ of their sample claimed to be "nervous persons" and to have had panic attacks, respectively. Of some note is that their questionnaire did not define these terms further. The study showed very little use of alcohol or drugs of abuse, while $4 \%$ of the "impaired" group admitted to the use of prescription medications to control performance anxiety symptoms; beta-blocking agents were not specifically questioned for. Though specific psychological psychotherapeutic techniques were not detailed, over $50 \%$ of the respondents reported their use for the management of performance anxiety.

Fishbein and Middlestadt (24) completed a major survey of over 2,000 professional musicians and found that $24 \%$ of the respondents reported "stage fright" as a significant medical problem; it was (along with eye strain) their most reported medical complaint. However, the authors did not define "stage fright" in terms of discrete physical and psychological symptoms. They also noted "acute anxiety" as being reported as a medical problem by $13 \%$ of their respondents. Perhaps some of this latter group had panic disorder symptoms not temporally-connected to performance. Other psychologic symptoms cited by the respondents were depression in $17 \%$, sleep disturbances in $14 \%$, and concern over alcohol consumption in $20 \%$. Twenty-seven percent of the respondents had used beta-adrenergic blocking agents (70\% of these were "non-prescribed occasional" users). Occasional use of betablockers was most frequent before auditions, solo recitals, or difficult orchestratal performances. The vast majority of those musicians who used beta-blockers on such an occasional basis reported success in stage fright symptom control. Twenty-five percent of the stage fright sufferers had resorted to psychological counseling (tech- 
nique unspecified) for symptom relief, with $60 \%$ reporting success. It has been claimed that conflicts over career choice and domestic turmoil may be somewhat responsible for the experience of performance anxiety in the musician (25).

Various athletic events which require fine motor control can be adversely affected by the physical symptoms of performance anxiety. For example, the rifle shooter or archer can be rendered unsteady by palpitations or tremor. The bowler, billiards player, or golfer will be ill-served by either sweaty palms or hand tremor. At a more cognitive level, focusing on others' ability to see the signs of performance anxiety can serve to distract the competitor and keep him from concentrating on his athletic skill (26).

Actors and public speakers can be affected by performance anxiety symptoms as well. It is difficult to maintain concentration on one's speaking performance in the face of palpitations, sweating, tremor or the other symptoms of performance anxiety. Also troublesome to the speaker are dry mouth, vocal tremor, and shortness of breath.

\section{BETA-ADRENERGIC BLOCKING AGENTS-RATIONALE FOR TREATMENT}

Beta-adrenergic blocking agents are thought to act peripherally to block the somatic components of the anxiety state. These symptoms include tachycardia/ palpitations, tremor, and sweating, as well as various other symptoms (Table 1). By blockade of the peripheral manifestations of anxiety, the patient perceives less anxiety, thus blunting the positive feedback loop wherein the perception of somatic anxiety symptoms leads to anxious thoughts which leads to more somatic symptoms. It has long been appreciated that sympathetic nervous system discharge is associated with such symptoms; beta-adrenergic blockade is thus a treatment consistent with physiology.

It has generally been shown that the action of beta-blockers in reducing anxiety symptoms is based on their peripheral actions; beta-blocking agents known not to penetrate the blood-brain barrier may reduce anxiety symptoms, and anxiolysis has been noted with beta-blocker doses too low to achieve central physiological effects (27). Furthermore, in anxiety states, the action of beta-blockers on peripheral manifestations are more clearly reduced than are the purely psychic manifestations, and various performance acts are improved with just the peripheral actions of beta-blockers $(11,13)$.

A study by Mills, Dimsdale, Ziegler et al. (28) found lymphocyte beta-adrenergic receptor density and sensitivity to correlate with the cardiovascular response to a mental stressor. This is of interest in that excess cardiovascular reactivity may predict the later development of cardiovascular disease; it is plausible that excess cardiovascular reactivity may correlate with the degree of performance anxiety symptoms as well.

Foster, Evans and Hardcastle (29) monitored the pulse rates of surgeons while they performed operations and while they attended outpatient clinics. A typical increase in pulse to a mean of $121 \mathrm{BPM}$ was seen in the surgeons while they were 
TABLE 1.

Signs / Symptoms of Performance Anxiety (1-16)

Neuropsychiatric
TREMOR
nervousness
fear
increased talking
restlessness
decreased concentration
increased muscle tension
"detached" feeling
tingling
Cardiovascular
TACHYCARDIA/PALPITATIONS
hypertension
Respiratory
Shortness of Breath
Gastrointestinal
Nausea
Diarrhea
Dermatologic
SWEATING
flushed skin/blushing
Other
Dry Mouth
Voice Change
Urgency to Micturition

operating; $40 \mathrm{mg}$ of oxprenolol reduced the during surgery pulse of the surgeons to a mean of 84 BPM.

Chronic administration of beta-adrenergic blocking agents is associated with an increase in the number of beta-adrenergic receptors; thus abrupt discontinuation of these agents can cause a withdrawal syndrome. The withdrawal symptoms may include anxiety, tremulousness, sweating and tachycardia (16). The notable similarity between these symptoms and the symptoms of performance anxiety make the "peripheral somatic cues" model of performance anxiety and its management by beta-adrenergic blockade all the more plausible.

\section{STUDIES OF BETA-ADRENERGIC BLOCKADE FOR PERFORMANCE ANXIETY} AND/OR SOCIAL PHOBIA (TABLE 2)

Hartley, Ungapen, Davie and Spencer (1) studied public speakers who received either $40 \mathrm{mg}$ propranolol or placebo sixty to ninety minutes prior to giving a speech. In part of their study, "anxious" group was selected on the basis of their high scores on a scale of trait anxiety. Following the speech, the subjects completed a scale of state anxiety. Propranolol was associated with a significant decrease in the state anxiety 
TABLE 2.

Studies of Beta-Adrenergic Blocking Agents for Symptoms of Performance Anxiety/Social Phobia

\begin{tabular}{|c|c|c|c|c|c|}
\hline Authors: & $\begin{array}{l}\text { Medica- } \\
\text { tions: }\end{array}$ & Design: & $\begin{array}{l}\text { Performance } \\
\text { Task: }\end{array}$ & Results: & Comments: \\
\hline $\begin{array}{l}\text { Hartley, Ungapen, } \\
\text { Davie, et al. (1) }\end{array}$ & $\begin{array}{l}\text { Propranolol } \\
\quad 40 \mathrm{mg}\end{array}$ & $\begin{array}{l}\text { Double Blind } \\
\text { Cross-over } \\
\text { Placebo Con- } \\
\quad \text { trolled }\end{array}$ & Public Speaking & $\begin{array}{l}\text { Propranolol decreased anxiety } \\
\text { symptoms in nonverbal behav- } \\
\text { ior of anxious subjects and de- } \\
\text { creased pulse rate in all sub- } \\
\text { jects. }\end{array}$ & $\begin{array}{l}\text { Propranolol delayed recall } \\
\text { of items in some subjects, } \\
\text { raising question of a cen- } \\
\text { tral action. }\end{array}$ \\
\hline $\begin{array}{l}\text { James, Pearson, } \\
\text { Griffith, New- } \\
\text { bury (2) }\end{array}$ & $\begin{array}{l}\text { Oxprenolol } \\
\quad 40 \mathrm{mg}\end{array}$ & $\begin{array}{l}\text { Double Blind } \\
\text { Cross-over } \\
\text { Placebo Con- } \\
\quad \text { trolled }\end{array}$ & $\begin{array}{l}\text { Music (Instru- } \\
\text { mental-strings) }\end{array}$ & $\begin{array}{l}\text { Oxprenolol decreased pulse, sys- } \\
\text { tolic BP, tremor, self-ratings of } \\
\text { nervousness, and improved mu- } \\
\text { sic performance scores. Calm- } \\
\text { ing effect attributed to oxpre- } \\
\text { nolol. }\end{array}$ & $\begin{array}{l}\text { Oxprenolol had no effect on } \\
\text { memory, and had more } \\
\text { effect on first day of } \\
\text { treatment. }\end{array}$ \\
\hline James, Savage (3) & $\begin{array}{l}\text { Nadolol } \\
40 \mathrm{mg} \\
\text { Diazepam } \\
2 \mathrm{mg}\end{array}$ & $\begin{array}{l}\text { Double Blind } \\
\text { Cross-over } \\
\text { Placebo Con- } \\
\quad \text { trolled }\end{array}$ & $\begin{array}{l}\text { Music (Instru- } \\
\text { mental-strings) }\end{array}$ & $\begin{array}{l}\text { Nadolol decreased skin flushing, } \\
\text { self-rating of trembling, pulse } \\
\text { rate, and improved bowing } \\
\text { technique, intonation, and } \\
\text { overall musical performance. }\end{array}$ & $\begin{array}{l}\text { Nadolol was chosen for its } \\
\text { hydrophilicity. }\end{array}$ \\
\hline $\begin{array}{l}\text { Brantigan, Branti- } \\
\text { gan, Joseph (4) }\end{array}$ & $\begin{array}{l}\text { Propranolol } \\
\quad 40 \mathrm{mg} \\
\text { Terbutaline }\end{array}$ & $\begin{array}{l}\text { Double Blind } \\
\text { Cross-over } \\
\text { Placebo Con- } \\
\text { trolled }\end{array}$ & $\begin{array}{l}\text { Music (Instru- } \\
\text { mental) }\end{array}$ & $\begin{array}{l}\text { Propranolol decreased pulse } \\
\text { and improved self-ratings } \\
\text { symptoms, musical perfor- } \\
\text { mance, and saliva volume. }\end{array}$ & $\begin{array}{l}\text { Terbutaline worsened per- } \\
\text { formance anxiety symp- } \\
\text { toms. }\end{array}$ \\
\hline $\begin{array}{l}\text { Neftel, Adler, } \\
\text { Kappeli, et al. } \\
(30)\end{array}$ & $\begin{array}{l}\text { Atenolol } \\
100 \mathrm{mg}\end{array}$ & $\begin{array}{l}\text { Double Blind } \\
\text { Placebo Con- } \\
\text { trolled }\end{array}$ & $\begin{array}{l}\text { Music (Instru- } \\
\text { mental-strings) }\end{array}$ & $\begin{array}{l}\text { Atenolol decreased pulse and self- } \\
\text { ratings of performance anxiety } \\
\text { symptoms during performance } \\
\text { only; atenolol improved some } \\
\text { technical aspects of perfor- } \\
\text { mance. }\end{array}$ & $\begin{array}{l}\text { Atenolol was chosen for its } \\
\text { hydrophilicity. Placebo } \\
\text { group showed increased } \\
\text { pulse beginning } 90 \text { sec- } \\
\text { onds before performance } \\
\text { that lasted throughout } \\
\text { performance. }\end{array}$ \\
\hline
\end{tabular}


TABLE 2.

Continued

\begin{tabular}{|c|c|c|c|c|c|}
\hline Authors: & $\begin{array}{l}\text { Medica- } \\
\text { tions: }\end{array}$ & Design: & $\begin{array}{l}\text { Performance } \\
\text { Task: }\end{array}$ & Results: & Comments: \\
\hline $\begin{array}{l}\text { Gates, Saegert, } \\
\text { Wilson, et al. } \\
\text { (5) }\end{array}$ & $\begin{array}{l}\text { Nadolol } \\
20,40,80 \\
\mathrm{mg}\end{array}$ & $\begin{array}{l}\text { Double Blind } \\
\text { Placebo Con- } \\
\text { trolled }\end{array}$ & Music (Singing) & $\begin{array}{l}\text { Nadolol decreased intra-perfor- } \\
\text { mance pulse rate at all doses. } \\
20 \text { mg dose-improved perfor- } \\
\text { mance by self-rating and judg- } \\
\text { es' ratings. } 40 \mathrm{mg}, 80 \mathrm{mg} \\
\text { doses-worsened performance } \\
\text { by self-rating and judges' rat- } \\
\text { ings. }\end{array}$ & $\begin{array}{l}\text { Many subjects described } \\
\text { decreased "energy" at } \\
\text { higher doses. Small num- } \\
\text { ber of subjects prevented } \\
\text { authors from concluding } \\
\text { clear benefit of lower } \\
\text { dose. }\end{array}$ \\
\hline $\begin{array}{l}\text { Liden, Gottfries } \\
\quad(6)\end{array}$ & $\begin{array}{l}\text { Alprenolol } \\
50,100 \\
\mathrm{mg}\end{array}$ & $\begin{array}{l}\text { Double Blind } \\
\text { Cross-over } \\
\text { Placebo Con- } \\
\quad \text { trolled }\end{array}$ & $\begin{array}{l}\text { Music (Instru- } \\
\text { mental) }\end{array}$ & $\begin{array}{l}\text { Alprenolol decreased pulse rate, } \\
\text { tremor, and blocked increase in } \\
\text { muscle tone. }\end{array}$ & $\begin{array}{l}\text { Subjects were self-selected } \\
\text { for performance anxiety } \\
\text { symptoms. }\end{array}$ \\
\hline $\begin{array}{l}\text { James, Buygoyne, } \\
\text { Savage (31) }\end{array}$ & $\begin{array}{l}\text { Pindolol } \\
5 \mathrm{mg}\end{array}$ & $\begin{array}{l}\text { Double Blind } \\
\text { Placebo Con- } \\
\text { trolled }\end{array}$ & $\begin{array}{l}\text { Music (Instru- } \\
\text { mental) }\end{array}$ & $\begin{array}{l}\text { Pindolol decreased anxiety, pulse, } \\
\text { blood pressure increase, and } \\
\text { improved subjective evaluation } \\
\text { of performance. }\end{array}$ & $\begin{array}{l}\text { Pindolol had no effect on } \\
\text { peak flows. }\end{array}$ \\
\hline Brewer (32) & $\begin{array}{l}\text { Propranolol } \\
10-80 \mathrm{mg}\end{array}$ & $\begin{array}{l}\text { Placebo Con- } \\
\text { trolled }\end{array}$ & $\begin{array}{l}\text { University Exami- } \\
\text { nations }\end{array}$ & $\begin{array}{l}\text { Propranolol "suggestive" of im- } \\
\text { proved performance in "high } \\
\text { test anxiety" subjects. }\end{array}$ & $\begin{array}{l}\text { Propranolol doses were ad- } \\
\text { justed to achieve resting } \\
\text { pulse rate of 55-65 BPM. }\end{array}$ \\
\hline $\begin{array}{l}\text { Taggart, Carru- } \\
\text { thers, Somer- } \\
\text { ville (13) }\end{array}$ & $\begin{array}{l}\text { Oxprenolol } \\
40 \mathrm{mg}\end{array}$ & $\begin{array}{l}\text { Double Blind } \\
\text { Cross-over } \\
\text { Placebo-Con- } \\
\quad \text { trolled }\end{array}$ & Public Speaking & $\begin{array}{l}\text { Oxprenolol blocked tachycardia } \\
\text { and EKG abnormalities, re- } \\
\text { lieved anxiety symptoms. }\end{array}$ & $\begin{array}{l}7 \text { patients in oxprenolol } \\
\text { group had known coro- } \\
\text { nary artery disease. }\end{array}$ \\
\hline $\begin{array}{l}\text { Drew, Barnes, } \\
\text { Evans (33) }\end{array}$ & $\begin{array}{l}\text { Propranolol } \\
120 \mathrm{mg}\end{array}$ & $\begin{array}{l}\text { Double Blind } \\
\text { Cross-over } \\
\text { Placebo-Con- } \\
\quad \text { trolled }\end{array}$ & $\begin{array}{l}\text { Verbal Reasoning } \\
\text { Mental Arith- } \\
\text { metic }\end{array}$ & $\begin{array}{l}\text { Propranolol associated with im- } \\
\text { proved performance. }\end{array}$ & $\begin{array}{l}\text { Students reporting anxiety } \\
\text { symptoms were helped } \\
\text { most. Side effects re- } \\
\text { ported in nearly half of } \\
\text { subjects on propranolol. }\end{array}$ \\
\hline
\end{tabular}


TABLE 2.

Continued

\begin{tabular}{|c|c|c|c|c|c|}
\hline Authors: & $\begin{array}{l}\text { Medica- } \\
\text { tions: }\end{array}$ & Design: & $\begin{array}{l}\text { Performance } \\
\text { Task: }\end{array}$ & Results: & Comments: \\
\hline $\begin{array}{l}\text { Siitonen, Janne } \\
\text { (34) }\end{array}$ & $\begin{array}{l}\text { Oxprenolol } \\
40 \mathrm{mg}\end{array}$ & $\begin{array}{l}\text { Double Blind } \\
\text { Cross-over } \\
\text { Placebo-Con- } \\
\quad \text { trolled }\end{array}$ & Bowling & $\begin{array}{l}\text { Oxprenolol blocked tachycardia, } \\
\text { improved scores in subgroup } \\
\text { with high cardiovascular reac- } \\
\text { tivity. }\end{array}$ & $\begin{array}{l}\text { Subjects without high car- } \\
\text { diovascular reactivity had } \\
\text { worse scores with oxpre- } \\
\text { nolol. }\end{array}$ \\
\hline $\begin{array}{l}\text { Liebowitz, Gor- } \\
\text { man, Fyer, et al. } \\
\quad(11,14)\end{array}$ & $\begin{array}{l}\text { Atenolol } \\
50,100 \\
\text { mg/day } \\
\text { Phenelzine } \\
15-90 \\
\text { mg/day }\end{array}$ & $\begin{array}{l}\text { Double Blind } \\
\text { Placebo Cion- } \\
\text { trolled }\end{array}$ & None & $\begin{array}{l}\text { Phenelzine decreased symptoms } \\
\text { of generalized social phobia; } \\
\text { atenolol was no better than pla- } \\
\text { cebo for generalized social pho- } \\
\text { bia, but effective for discrete } \\
\text { social phobia. }\end{array}$ & $\begin{array}{l}\text { "Discrete" social phobia } \\
\text { similar to performance } \\
\text { anxiety. }\end{array}$ \\
\hline $\begin{array}{l}\text { Gorman, Liebow- } \\
\text { itz, Fyer, et al. } \\
\text { (12) }\end{array}$ & $\begin{array}{l}\text { Atenolol } \\
50,100 \\
\text { mg/day }\end{array}$ & $\begin{array}{l}\text { Open } \\
\text { No Placebo }\end{array}$ & None & $\begin{array}{l}50 \% \text { of patients with "marked" } \\
\text { and } 40 \% \text { of patients with } \\
\text { "moderate" improvement in } \\
\text { social phobia self-ratings. }\end{array}$ & $\begin{array}{l}50 \% \text { of patients with social } \\
\text { phobia in study had his- } \\
\text { tory of depression; } 50 \% \\
\text { had history of alcohol } \\
\text { abuse. Performance anxi- } \\
\text { ety patients not distin- } \\
\text { guished from those with } \\
\text { generalized social phobia. }\end{array}$ \\
\hline
\end{tabular}


scores, as well as a decrease in the observer ratings for signs of anxiety. Of note is the fact that the observer instrument was an "anxiousness" scale of one to 20; it apparently did not address individual physical symptoms of anxiety. When the authors compared a group of anxious subjects (on the basis of state and trait anxiety scales) to a non-anxious group, it was found that propranolol significantly reduced the pulse rate in both groups, while observers looking for pauses, stammering, giggling and tremor noted less speech-related anxiety behavior in the anxious subjects following propranolol, but no effect of the drug on the non-anxious. This distinction implies a neurochemical difference between the two groups. Some impairment in recall of some items by anxious subjects seen with propranolol suggested a central effect of propranolol.

James, Griffith, Pearson and Newbury (2) studied string musicians receiving 40 mg oxprenolol vs. placebo. The subjects played a solo piece before an audience and completed rating scales for anxiety before and after the performance, as well as assessments of performance. Blood pressure and pulse were monitored, and experienced music raters evaluated the performance for various technical points, one of which was lack of tremor. When receiving oxprenolol, the subjects had lower pulse and blood pressure, less nervousness, and improvement in musical performance. The area of greatest improvement with the drug was with tremor. The subjects were not selected for nervousness, and those with a history of nervous or mental illness were excluded. The oxprenolol was noted to have a greater effect before the first performance, suggesting that symptoms may decrease with time. A weakness of this study was that the authors did not inquire as to specific physical symptoms experienced by the subjects.

James and Savage (3) compared the effects of $40 \mathrm{mg}$ nadolol and $2 \mathrm{mg}$ diazepam on string musicians in a placebo-controlled study. Nadolol was chosen for its hydrophilicity and low likelihood of CNS side effects. Subjects with a history of nervous illness were excluded. The observers noted the subjects' specific physical signs (tremor, sweating, flushed skin, talking and restlessness); the subjects rated themselves for palpitations, loss of concentration, gastrointestinal upset, trembling, detached feeling, and frequency of micturition, as well as a self-rating on the quality of their performance. The nadolol group was noted to be paler than controls. Four of 14 subjects had tremor with placebo; all of these improved after nadolol. Nadolol was associated with a lower pulse and improvement in bowing technique and intonation. No difference was found in mood states on a self-rating scale with active drug. Diazepam was associated with a minor deterioration in performance.

Brantigan, Brantigan and Joseph (4) studied instrumental musicians using propranolol and the beta-adrenergic agonist terbutaline. The subjects were evaluated for overall performance, nervousness, and somatic symptoms. The propranolol group showed a significant decrease in heart rate, an improvement in saliva production, and improvement in the self-reports of various physical symptoms of performance anxiety. The terbutaline, as predicted increased the symptoms. The subjects' state (but not trait) anxiety decreased with propranolol. The results of the music raters' evaluation of subjects' performance in part of their study was significantly better with propranolol. 
Neftel, Adler, Kappeli et al. (30) studied string players on atenolol vs. placebo and found the active drug to decrease various stage fright symptoms (on a stagefright rating scale consisting of two cognitive questions, two physical questions and two technical/musical questions) during the performance but not immediately before it. As in other studies, the active drug blocked the during-performance tachycardia. Urinary catecholamine measurements were consistent with sympathoadrenal activation by stress; the atenolol was felt to act by peripheral blockade of such activation and was associated with some improvement in technical performance. The main sympathetic activation occurred 90 seconds before the beginning of the performance. A shortcoming of this study was the relative lack of screening for physical symptoms.

Gates, Saegert, Wilson et al. (5) studied singers with $20 \mathrm{mg}, 40 \mathrm{mg}$, and $80 \mathrm{mg}$ of nadolol and showed a limitation of intraperformance heart rate with all doses. The music judges' ratings for the performances showed a slight preference for performance with $20 \mathrm{mg}$ nadolol vs. placebo, while the higher doses resulted in performance judged as significantly poorer. This correlated to the comments by some subjects that the higher doses decreased their energy. The authors did not report the effect of the medication on specific symptoms.

Liden and Gottfries (6) studied instrumental musicians on either $50 \mathrm{mg}$ or 100 $\mathrm{mg}$ alprenolol vs. placebo and found a clear improvement in severity of self-reports in two symptom groups; palpitation, increased muscle tone, and tremor were grouped as the "catecholamine syndrome" while other less specific symptoms (e.g., uneasiness, irritability, and headache) were grouped as "other symptoms." No difference was found between the two doses of alprenolol. No assessment of the quality of musical performance or observer ratings of signs of anxiety were reported.

James, Burgoyne and Savage (31) used pindolol on instrumental musicians in a placebo-controlled study. The subjects' pulse and blood pressure were measured before the performance. The subjects rated both their level of anxiety and their own performance, and the performance was evaluated by an experienced professional musician. The pindolol group showed significantly lower pulse and systolic blood pressure with the active drug, and a lower anxiety self-rating and higher performance ratings by the rater in the group of "better" players. This study did not specifically address the various physical symptoms of performance anxiety.

Brewer (32) studied the effect of oxprenolol vs. placebo on a "high anxiety" group of university students taking examinations. He started subjects at $10 \mathrm{mg}$ propranolol and increased doses until the subject's resting pulse was slowed to $60 \pm 5$ BPM. He concluded that there was an improved performance on examinations by those who would otherwise be adversely affected by high levels of anxiety, especially those students with prominent cardiovascular symptoms.

Taggart, Carruthers and Somerville (13) studied the effects of $40 \mathrm{mg}$ oxprenolol on subjects speaking before an audience. EKG monitoring of a group of his subjects with coronary artery disease revealed ST depression when those subjects spoke. The oxprenolol improved these EKG abnormalities and blocked the anxiety-associated tachycardia; their study did not address the other physical symptoms or mental symptoms of performance anxiety. 
Drew, Barnes and Evans (33) studied the effects of $120 \mathrm{mg}$ propranolol vs. placebo on student volunteers performing tests of verbal reasoning and mental arithmetic. The active drug group was shown to have improved scores in both performance tasks. Undesirable effects were seen in nearly half of the subjects receiving propranolol; the most frequently reported symptoms were nausea, headache, and weak legs. The major benefit of treatment was seen in a subgroup who described themselves as having anxiety symptoms. As only a single dose was used in this study, it is not possible to determine whether some of the cited side effects were dose related.

Siitonen and Janne (34) studied the effects of $40 \mathrm{mg}$ oxprenolol on bowlers in a placebo-controlled design. The oxprenolol prevented performance-related tachycardia and was associated with improved bowling scores in a subgroup of subjects who had exhibited a significantly higher heart rate before, during, and after the competition. This finding is consistent with the hypothesis that persons with substantial performance anxiety symptoms may have a higher degree of cardiovascular reactivity to performance stressors than other people.

Gorman, Liebowitz and Fyer et al. (12) studied ten subjects who met the DSM-III criteria for social phobia. The subjects all suffered from various physical complaints in social settings; of these symptoms, palpitations, sweating, and tremor were the most commonly reported. No effort was made to separate a performance anxiety subtype from generalized social phobia in this study, though none of the ten had a history of spontaneous panic attacks. Five of the subjects had a history of depression, and five had a history of alcohol abuse. Doses ranged from $50 \mathrm{mg}$ to 100 $\mathrm{mg}$ atenolol daily for the six weeks of the trial. Nine of the ten patients in this open, uncontrolled study cited "moderate" or "marked" improvement in their social phobia symptoms. Specific symptom improvement and physiological measures were not addressed.

Liebowitz, Gorman and Fyer et al. $(11,14)$ studied 87 patients who met the DSM-III criteria for social phobia in a randomized placebo-controlled trial of atenolol and the monoamine oxidase inhibitor phenelzine. Daily atenolol doses were either 50 or $100 \mathrm{mg}$ (mean, $95 \mathrm{mg}$ ) while daily phenelzine doses ranged from 45-90 mg (mean, $72 \mathrm{mg}$ ). Assessments included several anxiety and depression inventories, plus a social phobia scale, which included 12 discrete performance fears. Their findings were that phenelzine was more effective for generalized social phobia, while atenolol was helpful for the discrete performance-related social phobia. A difficulty with this study is the lack of clear distinctions between the generalized versus performance-related social phobia groups.

\section{PHARMACOLOGICAL PROPERTIES OF THE BETA-ADRENERGIC BLOCKING AGENTS STUDIED}

The pharmacologic properties of the beta-adrenergic blocking agents used in the previously discussed performance anxiety and social phobia studies are summarized in Table 3. The choice of a specific beta-adrenergic blocking agent for the treatment 
of the physical symptoms of performance anxiety depends substantially on two pharmacological properties: lipid vs. $\mathrm{H}_{2} \mathrm{O}$ solubility and receptor selectivity. Atenolol is a cardioselective (i.e., beta-one selective), hydrophilic agent $(20,27,35,36)$. As a result, its beta-adrenergic actions are more specific to the heart and to blocking tachycardia. Because of its hydrophilicity, atenolol has relatively poor blood-brain barrier penetration and thus less risk of the CNS side effects occasionally reported with more lipophilic beta-adrenergic blockers such as propranolol. The finding in the studies cited $(12,30)$ that atenolol has some success in blocking the symptoms of performance anxiety supports the hypothesis that such symptoms are mediated by a peripheral mechanism.

Propranolol, by contrast, is a nonselective and lipophilic agent. The incidence of CNS side effects from beta-adrenergic blockade is reported to be greater with the more lipophilic agents, yet is still infrequent, especially at clinically-acceptable doses (35). Based on the therapeutic effect of beta-adrenergic blocking agents on essential tremor, it has been recommended that a nonselective agent be used when tremor is a significant target symptom $(27,36)$.

Of the other beta-adrenergic blocking agents cited in the above studies, only pindolol (moderately lipophilic and nonselective) and nadolol (hydrophilic and nonselective) are in common use in the U.S. As all of the mentioned beta-adrenergic blocking agents cited showed at least some effect in symptomatic control of performance anxiety, and no psychiatric side effects were reported in the studies, it would

TABLE 3.

Pharmacological Properties of Beta-Adrenergic Blocking Agents Used in Performance Anxiety and Social Phobia Studies: $(32,33,37-40)$

\begin{tabular}{|c|c|c|c|c|}
\hline Beta-Blocker: & Lipophilicity: & Cardioselectivity: & $\begin{array}{l}\text { Relative } \\
\text { Potency: }\end{array}$ & Effectiveness: \\
\hline $\begin{array}{l}\text { Propranolol } \\
\text { (4 studies) }\end{array}$ & high & $(-)$ & 1.0 & $\begin{array}{l}\text { Effective in } 4 \text { studies }(1,4,32 \text {, } \\
\quad 34\end{array}$ \\
\hline $\begin{array}{l}\text { Oxprenolol } \\
\quad \text { (3 studies) }\end{array}$ & moderate & $(-)$ & $0.5-1.0$ & $\begin{array}{l}\text { Effective in } 2 \text { studies }(2,13) \\
\text { Effective in "High Cardiovas- } \\
\text { cular Reactivity" subgroup } \\
\text { in } 1 \text { study ( } 33)\end{array}$ \\
\hline $\begin{array}{l}\text { Alprenolol } \\
\text { (1 study) }\end{array}$ & moderate & $(-)$ & $0.3-1.0$ & Effective in 1 study (6) \\
\hline $\begin{array}{l}\text { Pindolol } \\
\quad \text { (1 study) }\end{array}$ & moderate & $(-)$ & 6.0 & Effective in 1 study (31) \\
\hline $\begin{array}{l}\text { Nadolol } \\
\quad \text { (2 studies) }\end{array}$ & low & $(-)$ & 1.0 & $\begin{array}{l}\text { Effective in } 1 \text { study ( } 3 \text { ) } \\
\text { Effective at } 20 \mathrm{mg} \text { dose, inef- } \\
\text { fective at } 40 \mathrm{mg}, 80 \mathrm{mg} \text { dose } \\
\text { in } 1 \text { study (5) }\end{array}$ \\
\hline $\begin{array}{l}\text { Atenolol } \\
\qquad(3 \text { studies })\end{array}$ & low & $(+)$ & 1.0 & $\begin{array}{l}\text { Effective in } 2 \text { studies }(12,30) \\
\text { Effective in "Discrete Social } \\
\text { Phobia" Subgroup in } 1 \text { study } \\
(11,14)\end{array}$ \\
\hline
\end{tabular}


seem appropriate to use any of them clinically. If tremor should not be controlled with atenolol, a change to a nonselective agent may be tried. Should the patient have a history of CNS side effects from a lipophilic beta-adrenergic blocker, a switch to a less lipophilic agent could be considered.

\section{OTHER PHARMACOLOGIC AND NONPHARMACOLOGIC TREATMENTS OF PERFORMANCE ANXIETY}

When performance anxiety is present with the generalized type of social phobia, pharmacologic treatment with the monoamine oxidase inhibitor phenelzine can be considered $(14,20,21,37)$. Doses to consider range between 45 and $90 \mathrm{mg}$ daily. The usual cautions apply regarding compliance with a tyramine-free diet and awareness of possible tyramine reaction.

For symptoms of performance anxiety, pharmacologic treatment should include benzodiazepines only with great caution. The risk of alcohol abuse in these patients makes the chance of benzodiazepine abuse significant. If used for this purpose, benzodiazepines should be short half-life agents (e.g., alprazolam, lorazepam) and used primarily on a limited, PRN basis.

Because of the possible confusion regarding panic disorder vs. social phobia, it may be that some patients presenting with performance-related anxiety symptoms are in fact sufferers of primary panic disorder. If this is a clinical possibility, the patient may respond better to tricyclic antidepressants (22).

For nonpharmacologic management of performance anxiety symptoms, various interventions have been recommended. Anxiety management training involves exposure to the phobic situations or a similar situation. An apt example is Toastmaster's Club for those with public speaking phobia (15,37). Relaxation training can be combined with the exposure to the phobic situation. The exposure therapy may be most successful when combined with cognitive therapy, wherein the therapist helps the patient to correct incorrect cognitions about the perceived consequences of his physical symptoms, and to replace negative expectations with more hopeful ones regarding performance (37).

Social skills training can be considered for those patients with associated social dysfunction. This may require a group format and may include assistance in communication and assertiveness. This may be particularly valuable for the patient who meets the criteria for avoidant personality disorder (15).

Whatever approach is taken for patients with the performance anxiety subtype of social phobia, pharmacologic treatment combined with psychologic intervention should have as a common goal symptom reduction, increased confidence in good performance, and consolidated, long-lasting improvement (7).

\section{SUMMARY AND RECOMMENDATIONS}

The evaluation and management of performance anxiety may challenge the psychiatrist's diagnostic, pharmacologic, medical, and psychotherapeutic skills. The 
patient who presents for help with disabling performance anxiety symptoms, particularly the musician, speaker, actor, or athlete, may be facing a career-threatening problem. There is little margin for error in performance for those who pursue those activities professionally.

Careful history taking for the physical symptoms of performance-related sympathetic nervous system discharge (tachycardia/palpitations, sweating, and tremor being the most commonly mentioned), consideration of a diagnosis of panic disorder if such symptoms first appeared spontaneously and are not always related to performance, and differentiation of limited social phobia from the more global disorders generalized social phobia and avoidant personality disorder are essential. The psychiatrist must also remain vigilant for concurrent depression, substance abuse/dependence, and other phobias that may be present in this population.

Once having determined that a patient does indeed suffer from a limited social phobia/performance anxiety, the clinician may consider beta-adrenergic blocker therapy. One must be mindful of resting bradycardia, diabetes mellitus, reactive airway disease, Raynaud's phenomenon and other medical conditions which would make beta-blocker therapy problematic. When beta-blocker therapy is to be tried, the clinician can start at a low dose (e.g., propranolol $20 \mathrm{mg}$ to $40 \mathrm{mg}$ or atenolol $50 \mathrm{mg}$ ) and titrate upwards to control troublesome symptoms (38). The patient should be taught to check his pulse and not take higher doses if the resting pulse is less than 60 BPM. Pulse and blood pressure should be checked on office visits. If the patient has a history of CNS side effects from beta-adrenergic blockade (including the ophthalmic preparations of timolol, levobunolol, and betaxolol), these agents should be used very cautiously.

For patients who face a symptomatically phobic stimulus only on occasion (e.g., the musician who has an occasional difficult audition or performance), the use of beta-adrenergic blockade on a PRN basis one or two hours prior to performance may be adequate. For the limited social phobic who must face his phobic challenge and perform well daily, daily dosing of the medication may be necessary. For the athlete who needs fine motor control (e.g., the archer, golfer, or billiards player), the clinician must learn whether the use of beta-blockers would violate the rules of the sport's governing body. Beta-adrenergic blocking agents are not among substances banned for Olympic athletes (39).

It may be most effective to combine pharmacotherapy with behavioral therapy, cognitive restructuring and when needed social skills training to achieve lasting results for this challenging clinical problem.

\section{ACKNOWLEDGEMENTS:}

The views expressed herein are those of the author and do not represent the official position of the Department of the Air Force, the Department of Defense, or other U.S. federal agencies.

The author would like to thank the Wright State University Word Processing Center for preparation of the manuscript and Cathy Constance, A.M.L.S., for her invaluable library research assistance. 


\section{REFERENCES}

1. Hartley LR, Ungapen S, Davie I, et al.: The effect of beta-adrenergic blocking drugs on speakers' performance and memory. British Journal of Psychiatry 142:512-517, 1983

2. James IM, Griffith DNW, Pearson RM, Newbury P: Effect of oxprenolol on stage fright in musicians. The Lancet ii:952-954, 1977

3. James I, Savage I: Beneficial effect of nadolol on anxiety-induced disturbances of performance in musicians: A comparison with diazepam and placebo. American Heart Journal 1984; 4 Part 2:1150-1155

4. Brantigan CO, Brantigan TA, Joseph N: Effect of beta blockade and beta stimulation on stage fright. American Journal of Medicine 72:88-94, 1982

5. Gates GA, Saegert J, Wilson N, et al.: Effects of beta blockade on singing performance. Annals of Otology, Rhinology, Laryngology 94:570-574, 1985

6. Liden S, Gottfries CG: Beta-blocking agents in the treatment of catecholamine-induced symptoms in musicians. The Lancet ii:529, 1974

7. Lockwood AH: Medical problems of musicians. New England Journal of Medicine 320:221227,1989

8. Noyes R: Beta-blocking drugs and anxiety. Psychosomatics 23:155-170, 1982

9. Ziporyn T: Pianist's cramp to stage fright: The medical side of music-making. Journal of the American Medical Association 252:985-989, 1984

10. Wesner RB, Noyes R, Davis TL: The occurrence of performance anxiety among musicians. Journal of Affective Disorders 18:177-185, 1990

11. Liebowitz MR, Gorman JM, Fyer AJ, et al.: Pharmacotherapy of social phobia: An interim report of a placebo-controlled comparison of phenelzine and atenolol. Journal of Clinical Psychiatry 49:252-257, 1988

12. Gorman JM, Liebowitz MR, Fyer AJ, et al.: Treatment of social phobia with atenolol. Journal of Clinical Psychopharmacology 5:298-301, 1985

13. Taggart P, Carruthers M, Somerville W: Electrocardiogram, plasma catecholamines and lipids, and their modification by oxprenolol when speaking before an audience. The Lancet ii:341-346, 1973

14. Liebowitz MR: Psychopharmacological management of social and simple phobias, in The Clinical Management of Anxiety Disorders. Edited by Coryell W, Winokur G. New York and Oxford, Oxford University Press, 1991

15. Agras WS: Treatment of Social Phobias. Journal of Clinical Psychiatry 1990; 51 (Supplement):52-55

16. Dominguez RA, Goldstein BJ: Beta-blockers in psychiatry. Hospital and Community Psychiatry 35:565-568, 1984

17. Diagnostic and Statistical Manual of Mental Disorders, Third Edition-Revised (DSM-IIIR). Washington, The American Psychiatric Association, 1987

18. Heimberg RG, Hope DA, Dodge CS, Becker RE: DSM-III-R subtypes of social phobia: Comparison of generalized social phobics and public speaking phobics. Journal of Nervous and Mental Disease 178:172-179, 1990

19. Turner SM, Beidel DC: Empirically derived subtypes of social anxiety. Behavior Therapy 16:384-392, 1985

20. Liebowitz MR, Campeas R, Levin A, et al.: Pharmacotherapy of social phobia. Psychosomatics 28:305-308, 1987

21. Liebowitz MR, Gorman JM, Fyer AJ, Klein DF: Social phobia: Review of a neglected anxiety disorder. Archives of General Psychiatry 42:729-736, 1985 
22. Pohl R, Balon R, Yergani VK: Performance anxiety and panic disorder. Journal of Clinical Psychopharmacology 8:225-226, 1988

23. Clark DB: Performance-related medical and psychological disorders in instrumental musicians. Annals of Behavioral Medicine 11:28-34, 1989

24. Fishbein M, Middlestadt SE with Ottati V, et al.: Medical problems among ICSOM musicians: Overview of a national survey. Medical Problems of Performing Artists 3:1-8, 1988

25. Nagel JJ: Musicians' maladies. New England Journal of Medicine 32 1:51-52, 1989

26. Waitley DE, May JR, Martens R: Sports psychology and the elite athlete. Clinics in Sports Medicine 2:87-99, 1983

27. Tyrer PJ: Use of beta-blocking drugs in psychiatry and neurology. Drugs 20:300-308, 1980

28. Mills PJ, Dimsdale JE, Ziegler MG, et al.: Beta-adrenergic receptors predict heart rate reactivity to a psychosocial stressor. Psychosomatic Medicine 52:621-623, 1990

29. Foster GE, Evans DF, Hardcastle JD: Heart rates of surgeons during operations and other clinical activities and their modification by oxprenolol. The Lancet ii:1323-1325, 1978

30. Neftel KA, Adler RH, Kappeli L, et al.: Stage fright in musicians: A model illustrating the effects of beta-blockers. Psychosomatic Medicine 44:461-469, 1982

31. James IM, Burgoyne W, Savage IT: Effect of pindolol on stress-related disturbances of musical performance: Preliminary communication. Journal of the Royal Society of Medicine 76:194-196, 1983

32. Brewer C: Beneficial effect of beta-adrenergic blockade on "exam nerves." The Lancet ii: 435,1972

33. Drew PJT, Barnes JN, Evans SJW: The effect of acute beta-adrenoreceptor blockade on examination performance. British Journál of Clinical Pharmacology 19:783-786, 1985

34. Siitonen L, Janne J: Effect of beta-blockade during bowling competition. Annals of Clinical Research 8:393-398, 1976

35. McAinsh J, Cruickshank JM: Beta-blockers and central nervous system side effects. Pharmacology and Therapeutics 46:163-197, 1990

36. El-Mallakh RS: The use of beta-blockers in psychiatry. Resident and Staff Physician $35: 49-52,59,62,1989$

37. Noyes R: Treatments of choice for anxiety disorders, in The Clinical Management of Anxiety Disorders. Edited by Coryell W, Winokur G. New York and Oxford, Oxford University Press, 1991

38. Hallett M: Classification and treatment of tremor. Journal of the American Medical Association 266:1115-1117, 1991

39. Strauss RH: Drugs in Sports, in Sports Medicine. Edited by Strauss RH. Philadelphia, W.B. Saunders Company, 1984

40. Weiner N: Drugs that inhibit adrenergic nerves and block adrenergic receptors, in Goodman and Gilman's The Pharmacological Basis of Therapeutics, 7th Edition. Edited by Goodman Gilman A, Goodman LS, Rall TW, Murad F. New York, MacMillan Publishing Co., 1985

41. Katzung BG: Introduction, in Basic and Clinical Pharmacology, 3rd Edition. Edited by Katzung BG. Norwalk CT and Los Altos CA, Appleton and Lange, 1987

42. Drug Evaluations, 6th Edition. American Medical Association. Philadelphia, W.B. Saunders Company, 1987

43. McMahon FG: Management of Essential Hypertension: The New Low-Dose Era. Mount Kisco NY, Futura Publishing Co., 1984 